\title{
Evaluation of an Experimental Virtual Learning Environment of Winemaking for Middle School and College Students in Chile
}

\author{
Evaluación de un ambiente virtual de aprendizaje de vinificación para estudiantes de \\ enseñanza media y superior en Chile
}

\section{Avaliação de um ambiente virtual de aprendizagem para os alunos vinificação ensino secundário e superior no Chile}

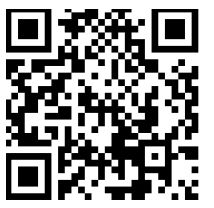

Recibido • Received • Recebido: 15 / 09 / 2016

Corregido • Revised • Revisado: 20 / 02 / 2018

Aceptado•Accepted • Aprovado: 06/ 03 / 2018

\footnotetext{
${ }^{1}$ Is an enologist and associate professor in the Forestry and Agronomy Faculty at Universidad Católica del Maule where his primary responsibility is for teaching on the oenology sciences in the school of Agronomy. He has been involved as author in four wine education software. He was the general director of the CONICYT project "Virtual winemaking: developing work competences for the wine industry" and technical director of the Maule network of wine industry in order to define the work competences standards.

${ }^{2}$ Is professor in the Forestry and Agronomy Faculty at Universidad Católica del Maule. He earned his Ph D in the Universidad de Chile (2012), focusing on breeding and plant physiology. His main research interests are the use of ICTs to improve undergraduate and postgraduate students' learning and performance. Dr. Espinoza actively participated in the evaluation of the BITWINE VLE.
} 
doi: http://dx.doi.org/10.15359/ree.22-2.13

URL: http://www.una.ac.cr/educare

CORREO: educare@una.cr

\begin{abstract}
BITWINE is a virtual learning environment (VLE) that was aimed to develop work competencies in the winemaking industry based on Chilean winemaking work standards. This paper analyzed the learning of the winemaking process as well as the likeability and functionality of BITWINE for university and technical school students. The learning with BITWINE was tested through quasiexperimental tests for groups control (with BITWINE) and experimental (without BIWINE) with written assessment. Furthermore, functionality and likeability perceptions, obtained through written surveys, are analyzed and discussed. The results showed that those students who used BITWINE improved their learning. The perception of BITWINE likeability demonstrated that it was well designed. The studied VLE also contributed to teach how to work with appropriate norms of traceability, hygiene and work safety. However, although BITWINE was quite appreciated as an e-learning tool, it still requires better information and communications technology conditions to be functional.
\end{abstract}

Keywords: Architectures for educational technology system; improving classroom teaching; interactive learning environments; secondary education.

Resumen: BITWINE es un ambiente virtual de aprendizaje (AVA) cuyo propósito fue desarrollar competencias laborales para la industria del vino, basándose en los estándares chilenos de competencias laborales. El presente artículo analiza el aprendizaje adquirido en los procesos de vinificación, así como también la percepción acerca del atractivo y la funcionalidad del diseño de BITWINE por parte de estudiantado universitario y de escuelas técnicas. El aprendizaje con BITWINE fue evaluado mediante pruebas cuasi-experimentales. Además, se discuten y analizan las percepciones de funcionalidad y atractivo, las que fueron obtenidas a través de encuestas. Los resultados mostraron que quienes usaron BITWINE mejoraron su aprendizaje. La percepción del atractivo de BITWINE demostró que este fue bien diseñado. El AVA estudiado también contribuyó a enseñar cómo ejecutar las labores siguiendo normas de trazabilidad, higiene y seguridad laboral. Sin embargo, aunque BITWINE haya sido bien apreciado como herramienta de aprendizaje, requiere que las tecnologías de información y comunicación sean óptimas para funcionar adecuadamente.

Palabras claves: Arquitecturas para la tecnología de educación; mejoramiento de la enseñanza en clases; ambientes de aprendizajes interactivos; educación secundaria.

Resumo: Bitwine é um ambiente virtual de aprendizagem (AVA), cujo objetivo foi desenvolver habilidades de trabalhos para a indústria do vinho, com base nos padrões chilenos de competência de trabalho. Este artigo analisa as lições aprendidas no processo de vinificação, bem como a percepção dos atrativos e da funcionalidade do projeto Bitwine por estudantes universitários e de colégios técnicos. O aprendizado com Bitwine foi avaliado por meio de testes quase experimentais. Além disso, foi discutida e analisada as percepções de funcionalidade e capacidade de atração, obtidas por meio de pesquisas. Os resultados mostraram que aqueles que usaram Bitwine melhoraram sua aprendizagem. A percepção da atratividade de Bitwine mostrou que este programa foi bem desenhado. O estudo da AVA ajudou também a ensinar como realizar os trabalhos de acordo com as normas de acompanhamento, higiene e segurança no trabalho. No entanto, embora Bitwine foi bem avaliado como uma ferramenta de aprendizagem, exige que as tecnologias de informação e comunicação sejam excelentes para funcionar corretamente.

Palavras-chave: Arquiteturas para a tecnologia de educação; melhora no ensino em sala de aula; ambientes de aprendizagem interativos; educação profissional. 


\section{Introduction}

The Chilean wine industry disputed an excellent reputation around the world (Bisson, Waterhouse, Ebeler, Walker \&, Lapsley, 2002) and the Maule Region is the most developed wine production area in terms of production and amount of training and technical careers for the wine industry (MINEDUC, 2014); however, even though this productive sector is highly relevant to the workforce, the educative sector is not well prepared for the current challenges that require competent workers, especially for the intensive work of the annual vintage (Fredes, \& Viacava, 2007). This demand for competent workers has encouraged the technical educational institutions to modernize their curricula in order to satisfy the work competences of the wine industry in the Maule Region (Fredes, \& Viacava, 2007).

Bisson et al. (2002) noted that the wine industry requires the comprehension of the latest advances in the wide-ranging disciplines of science and technology. The Virtual Learning Environments (VLEs) are a technological tool that dramatically shifts the location and timing of education and training; VLEs provide users with an experiential environment for practice and repetition without on-the-job stress, especially where the limited access to technical winery equipment denies hands-on experience during the intensive seasonal period.

Some experiences in industries involving VLEs indicate that they have a great potential, especially in training applications based on the "learning by doing" approach (Tam, Badra, Marceau, Marin, \& Malowany, 1999). Dos Santos, Soares, Carvalho, \& Raposo (2012) indicate that VLEs allow the execution of different sequences of engineering simulations, improving the execution of large-scale engineering projects. For example, Zhou et al. (2012) developed a VLE that enables operators in automotive manufacturing to improve quality inspection. Brough et al. (2007) found that VLEs enable trainees to learn assembly operations in a virtual environment. Also, a significant amount of recent research on VLEs has been dedicated to the simulation of spatial manipulation tasks (Seth, Vance y Oliver, 2011), and to areas where mistakes in the assembly process are dangerous or expensive (Gamberini, Cottone, Spagnolli, Varotto, \& Mantovani, 2003); however, in the wine industry, no advances have been reached.

Based on the potential of VLEs to improve competences in the wine industry, the Chilean Scientific and Technology National Council supported the concept and construction of BITWINE, a virtual environment for training and practicing winemaking tasks. The Universidad Católica del Maule and Universidad Santo Tomás developed BITWINE between the years 2011 and 2013. With feedback from oenology teachers, oenologists, and expert winery operators, the most difficult processes in teaching and the most common mistakes were identified and served as a baseline scenario for the configuration of the seven processes included in BITWINE: i.e., crushing, pressing, fermentation, clarification, filtration, stabilization, and aging. The conceptual framework was defined considering the winemaking work competencies outlined in ChileValora (2015). 
doi: http://dx.doi.org/10.15359/ree.22-2.13

URL: http://www.una.ac.cr/educare

CORREO: educare@una.cr

The specific aims of this study were (1) to evaluate the learning of the winemaking process in secondary and technical school students through using and not using BITWINE and, (2) to analyze university students' perceptions of the likeability and functionality of BITWINE. Green, Ashton, \& y Felstead (2001) provide evidence of a strong correlation between the subset level of key skills (namely competences) and some specific work practices. Based on this, we hypothesized that the specific work practices designed in BITWINE will develop competences in the users, at least in the dimensions of understanding as well as in the abilities of job safety, traceability, and hygiene in the winemaking process. These subjects must be trained by the wine industry in order to meet the certification requirements of the demanding markets (Egan et al., 2007).

\section{Methodology}

General BITWINE description: BITWINE belongs to Universidad Católica del Maule and Universidad Santo Tomás, Chile. It is a VLE used for training and practicing job functions in winemaking, developed in Spanish by Unity ${ }^{\circledast}$ Game Development Engine and by ActionScript, Adobe Flash Player ${ }^{\circledR}$. The program was designed in 3D and 2D environments to facilitate the understanding, as well as the processes of a modern winery, and it appears to be the first VLE approach in a modern winery in which the students actually experience "being there" (Figure 1).

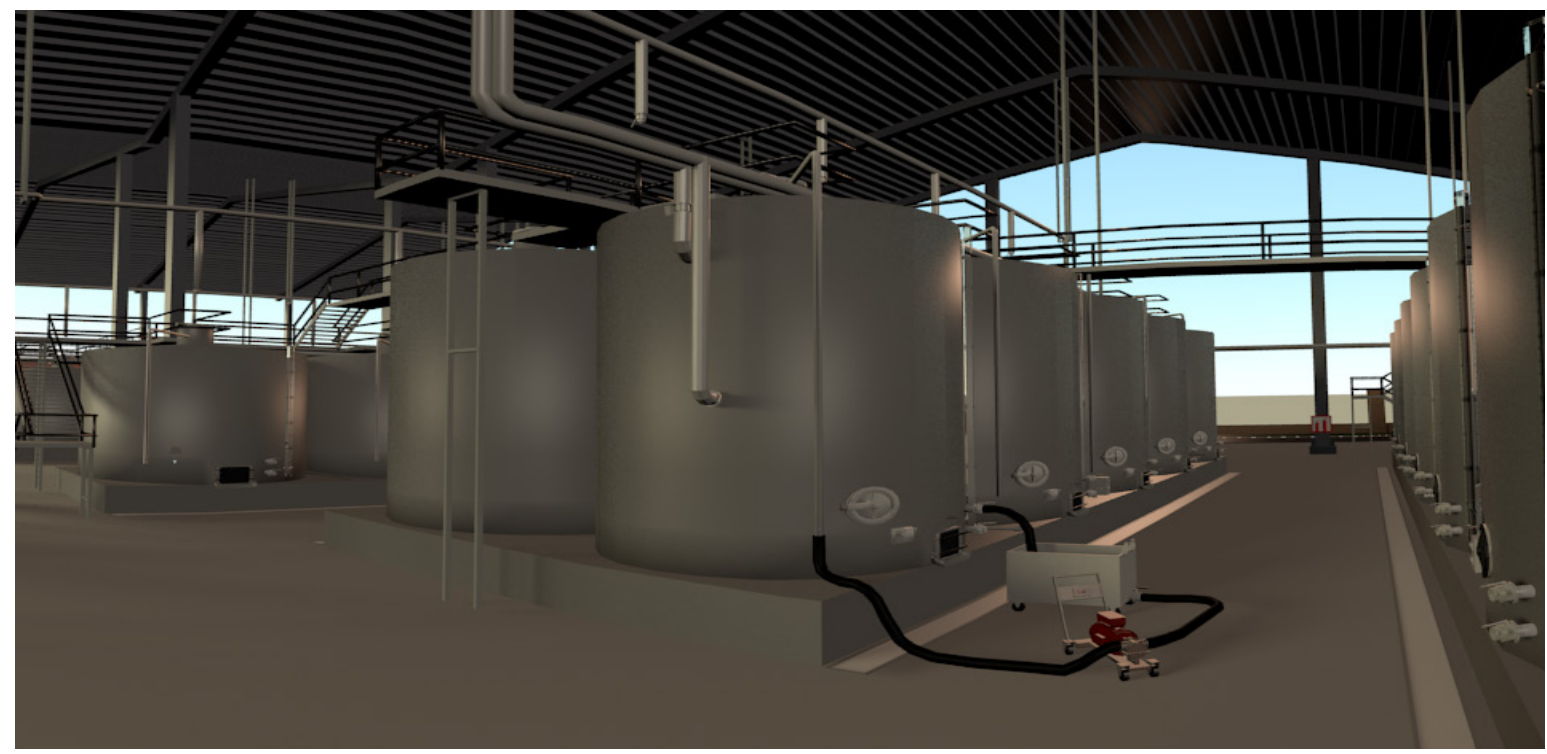

Figure 1: The virtual winery BITWINE 3D viewed from the floor.

Note: Personal compilation. 
The program contains a set of $2 \mathrm{D}$ flash animation infographics that display graphic information about the seven winemaking processes: crushing, fermentation, pressing, clarification, filtration, cold stabilization, and aging. Each process has three animations, corresponding to items such as equipment, operation and oenological incomes; with traceability and safety norms; and the hygiene processes involved in using the equipment (Figure 2).
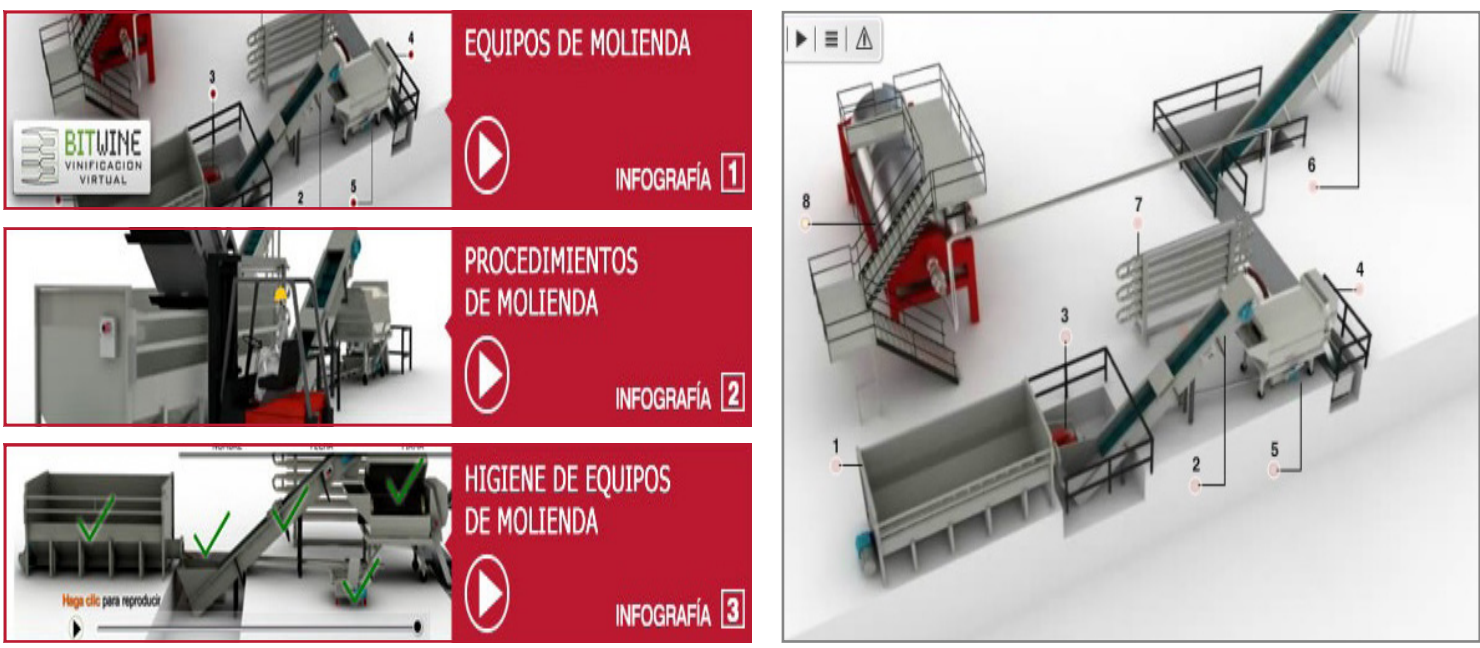

Figure 2: The left figure shows (description directly taken from the program, in Spanish) the three crushing animations (equipment, procedures, and hygiene). The image on the right shows equipment with hyperlinks that adds information about each part.

Note: Personal compilation.

The virtual winery is a separate module of BITWINE that was built on a 3D virtual environment in which the user can "walk, through an avatar" and experience basic equipment, tanks, cellars, barrel rooms, offices, laboratory, cooling system, and other equipment areas (Figure 1). Through the avatar, the user can go up the gangways and onto the tanks for a different point of view. The simulations start with a random work order from the virtual winery. The winemaking simulations reviewed in this paper were: crushing, pressing and fermentation.

Design and participants: The BITWINE evaluation was carried out during a period of nine months, beginning in October 2012 and ending by the end of July 2013, with students from The Professional Technical Institute, The College of Agronomy, and The Agricultural High School, all belonging to the Maule Region in Chile. The learning was evaluated through a quasi-experimental test, with both a written evaluation as well as a checklist. The schools allowed the randomly separation of the students at the beginning of the course of winemaking in two groups: control and experimental. Both groups were prepared at the same time, themes and conditions but the 
doi: http://dx.doi.org/10.15359/ree.22-2.13

URL: http://www.una.ac.cr/educare

CORREO: educare@una.cr

only difference of BITWINE incorporation for experimental group. The diagnostic assessment (pre test) was the same for both groups nevertheless the diagnostic assessment was not the same that the final assessment. The statistical differences between the control group (without BITWINE) and the experimental group (with BITWINE) were evaluated with a pre and a post test with a $t$-Test.

\section{Professional technical students}

In the case of the professional technical students, we conducted a quasi-experimental test in two different class courses (Table 1): one class course was the control group $(n=18)$ and the other one was the experimental group ( $n=17$ students). The experimental group worked with BITWINE during three class sessions with the animations of crushing grapes, and ending up with a written test about the crushing process. The control group learned about the same topic with the same teacher during an identical period, but with traditional classes (using power point presentations). The pre-test session was carried out during the first class for each group (i.e., control and experimental groups). The post-tests were applied through a written test for the same students in both the experimental as well as the control groups (i.e., a total of 35 students), which consisted of a recognition of the crushing equipment and the processes.

\section{Agricultural High School students}

Students from three different agricultural high schools were instructed with power point presentations, while other students were instructed with BITWINE by the same teacher. A pre-test, which consisted of questions to determine general student understanding of the winemaking process, was applied prior to beginning the instructions. Then, the students were randomly separated into control and experimental groups. The study topics were crushing and fermentation, in both groups. Following the instructions, the same students from the three schools responded to another post-test that consisted of a written knowledge test about the crushing and fermentation topics that students had just studied. The Agricultural High Schools had a different number of students according to enrollment: Liceo Agricola SSCC Villa Alegre (control group $n=4$, experimental group $n=4$ ); Liceo Agrícola San José de Duao (control group $n=20$, experimental group $n=16$ ) and Liceo Agrícola San Javier (control group $n=8$, experimental group $n=12$ ). The number of high school students was $n=32$ for the control and experimental group, respectively.

Instrument for the evaluation of perception about BITWINE: The students' perceptions were collected through surveys that were answered by $n=50$ university agronomy students during their introductory agronomy courses and $n=14$ university agronomy students in oenology courses (Tables 2 and 3). The freshmen agronomy students were questioned about the 
usability and functionality of BITWINE. The survey was conducted after four classes, where they learned about winemaking with BITWINE. Surveys about likeability, usability and functionality were applied to students after they had completed the crushing simulation. On the other hand, the specialized oenology students, learned, in class, with BITWINE for one semester, and they could freely access the animations and simulations as part of their extended learning experience outside of class. They were questioned about their general perception of BITWINE in the three BITWINE modules: infographic animations, 3D simulations, and animated e-learning activities.

Special emphasis was devoted to evaluating the capacity of BITWINE to teach about safety, traceability, and wine industry hygiene norms, which are the competence elements of Chilevalora (2015). Furthermore, students were questioned about two software attributes: functionality and likeability. In the case of BITWINE, functionality was understood as "a software feature that helps to develop competences in winemaking". Likeability was understood as the capacity of BITWINE to be "pleasant, friendly, and likable". The opinion of surveys was averaged and then expressed as a percentage of all the students.

\section{Results, analysis and discussion}

The survey results demonstrate that, in general, BITWINE simulates a real winery and winemaking processes well. Students of this study agreed that BITWINE improved their learning. Results draw special attention to BITWINE for improving students' ability to recognize equipment, processes, and inputs in the virtual world, and in turn, being able to apply that knowledge and practice to the real wineries. Cheng and Wang (2011) indicated that VLEs improve students' ability to move from an abstract thought to concrete implementation, thereby enhancing learning.

Evaluation of learning with BITWINE: After the intervention with BITWINE, overall, the experimental groups performed significantly better than the control groups on the post-test, even when a different test was applied, there were differences between control and experimental test. Table 1 shows that in most of the cases, the pre-test results do not demonstrate differences between the control and experimental groups $(p>0.05)$, but after intervention, the post-test results were significantly different $(p<0.01)$ between both groups and for all the cases analyzed.

The questions on the post-test had a higher degree of difficulty in comparison to questions presented on the pre-test. These differences were established purposefully to measure the real learning of students, instead of repeating the same questions before and after using BITWINE. This situation explains the differences between the Agricultural High Schools, showed in Table 1 , as well as explaining the decrease in their performance.

The performance of high school and technical school students improved significantly $(p<0.01)$ as a result of using BITWINE in the winemaking classes (Table 1). This difference, plus the general opinion of students who reported an improvement in their understanding after using BITWINE, 
doi: http://dx.doi.org/10.15359/ree.22-2.13

URL: http://www.una.ac.cr/educare

CORREO: educare@una.cr

corroborates the result that using BITWINE improves learning, which is coincident with the generally positive effect of simulations on learning (Rutten, van Joolingen, \& van der Veen, 2012; Verhagena, Feldberg, van den Hooff, Meents, \& Merikivi, 2011). Echeverría et al. (2012) pointed out that students significantly increased their conceptual understanding of electrostatics by using VLEs. Furthermore, in the field of chemical engineering education, which deals with chemical reaction engineering, VLEs have also demonstrated great potential for learning and training purposes since they reduce physical, safety, and cost constraints (Leronutti, \& Chittaro, 2007).

Table 1: Pre and post-test statistical analyses of the control and experimental groups for different student levels

\begin{tabular}{|c|c|c|c|c|c|}
\hline Evaluation tool and students provenance & Test & Group & $\mathrm{N}$ & $\begin{array}{c}\text { Media } \\
(\% \text { correct answers })^{1}\end{array}$ & $p$ value \\
\hline \multirow{4}{*}{$\begin{array}{l}\text { Written pre and post-test applied to Technical } \\
\text { students from "AIEP Curicó" }\end{array}$} & \multirow{2}{*}{ Pre-test } & Control & 18 & $46.5 a$ & \multirow{2}{*}{0.722} \\
\hline & & Experimental & 17 & $44.3 a$ & \\
\hline & \multirow{2}{*}{ Post-test } & Control & 18 & $38.2 \mathrm{a}$ & \multirow{2}{*}{$<0.01$} \\
\hline & & Experimental & 17 & $56.7 \mathrm{~b}$ & \\
\hline \multirow{4}{*}{$\begin{array}{l}\text { Written test applied to Agricultural High School } \\
\text { Students from "IER Villa Alegre" }\end{array}$} & \multirow{2}{*}{ Pre-test } & Control & 4 & $36.4 a$ & \multirow[t]{2}{*}{0.144} \\
\hline & & Experimental & 4 & $48.5 a$ & \\
\hline & \multirow{2}{*}{ Post-test } & Control & 4 & $22.7 \mathrm{a}$ & \multirow{2}{*}{$<0.01$} \\
\hline & & Experimental & 4 & $40.3 \mathrm{~b}$ & \\
\hline \multirow{4}{*}{$\begin{array}{l}\text { Written Test applied to Agricultural High School } \\
\text { Students from "CODESSER Duao" }\end{array}$} & \multirow{2}{*}{ Pre-test } & Control & 20 & $61.4 a$ & \multirow{2}{*}{0.898} \\
\hline & & Experimental & 16 & $62.5 \mathrm{a}$ & \\
\hline & \multirow{2}{*}{ Post-test } & Control & 20 & $10.1 \mathrm{a}$ & \multirow{2}{*}{$<0.01$} \\
\hline & & Experimental & 16 & $20.9 \mathrm{~b}$ & \\
\hline \multirow{4}{*}{$\begin{array}{l}\text { Written Test applied to Agricultural High School } \\
\text { Students from "Manuel Montt San Javier" }\end{array}$} & \multirow{2}{*}{ Pre-test } & Control & 8 & $47.4 a$ & \multirow{2}{*}{0.058} \\
\hline & & Experimental & 12 & $62.7 a$ & \\
\hline & \multirow{2}{*}{ Post-test } & Control & 8 & $16.4 \mathrm{a}$ & \multirow{2}{*}{$<0.01$} \\
\hline & & Experimental & 12 & $22.7 \mathrm{~b}$ & \\
\hline
\end{tabular}

${ }^{1}$ Different letters $(a, b)$ indicate significant differences ( $t$-Test). The pre and post test were different, hence the scale assessment also were different in each case.

Note: Personal compilation. 
Evaluation of the perception about BITWINE: The undergraduate students of oenology presented opinions about the functionality and the likeability of the BITWINE virtual program. The results of likeability were positive with respect to appearance and resemblance to a real winery. Furthermore, students "agreed and completely agreed" concerning the BITWINE learning activities (Tables 2 and 3). The functionality dimension also received a favorable opinion: BITWINE is a good learning tool, and an important percentage (Table 2) considered that it can successfully replace "real" hands-on instruction. The positive opinions with respect to BITWINE are consistent with Rutten et al., (2012) meta-analysis studies about the positive effect of simulators for learning in most cases.

Table 2: Opinions of freshmen Agronomy students

\begin{tabular}{lc}
\hline Likeability (Is BITWINE well designed?) & Positive answer (\%) \\
\hline Correctly simulates the appearance of a winery, giving students the feeling of "being there" & 100 \\
Work order appears to be real & 76 \\
Seems to contain truthful information & 71 \\
Does not have many unnecessary and excessive details & 95 \\
Uses proper symbols or winemaking icons & 93 \\
\hline
\end{tabular}

Functionality

Easily moves through the different simulated winemaking areas 92

Easily operates equipment and adds input $\quad 83$

Easily understands the order of the work $\quad 95$

Creates a positive learning experience $\quad 83$

$\begin{array}{ll}\text { Clearly instructs on how to complete the simulation successfully } & 76\end{array}$

Note: Personal compilation.

The survey response corroborates that the BITWINE design in 2D was a useful precedent for working with the 3D platform, as demonstrated by the additional opinions shown in Table 3, due to the fact that the 2D and 3D modules were designed to complement each other. Richards, \&Taylor (2015) indicated that both of them are good learning tools, and neither is better than the other as learning media. Brough et al. (2007) highlighted the importance of designing and implementing a believable virtual environment with clear images, simulations and processes. In particular, work places which require complex machines, careful measurements, time, and product quality need special attention in the design of such virtual spaces. As noted in the previous research, good environmental and architectural design elements and buildings inside the virtual learning environments can positively affect the learning process, user satisfaction, and contentment in the virtual worlds (Verhagena et al., 2011). 
doi: http://dx.doi.org/10.15359/ree.22-2.13

URL: http://www.una.ac.cr/educare

CORREO: educare@una.cr

The machinery operation, selection of process parameters, and the planning of the process are dimensions that present real and valuable learning for students interacting in virtual learning environments (Jou y Wang, 2013). The surveys indicated that students valued the virtual practice (Table 2 and 3 ) and statistically demonstrated that working with the simulations enabled them to learn faster. A high percentage of students also agreed that BITWINE addresses hygiene, work safety, and traceability norms (Table 3). The knowledge of job safety encourages students to learn more about personal protective equipment and safe work practices (Burke, Sarpy, Tesluk, \& Smith-Crowe, 2002) as well as learn about the ability to retrace steps and verify that certain events have taken place (traceability), especially in the hygienic process. This becomes a competitive advantage for manufacture industries (Alfaro, \& Rábade, 2009).

Table 3: General opinions of oenology students with respect to BITWINE

\begin{tabular}{|c|c|c|c|c|c|}
\hline Question & $\begin{array}{c}\text { Agree } \\
\text { completely } \\
(\%)\end{array}$ & $\begin{array}{c}\text { Agree } \\
\text { some-what } \\
(\%)\end{array}$ & $\begin{array}{l}\text { Neither agree } \\
\text { nor disagree } \\
\text { (\%) }\end{array}$ & $\begin{array}{c}\text { Disagre } \\
\text { some-what } \\
(\%)\end{array}$ & $\begin{array}{c}\text { Completely } \\
\text { disagree } \\
(\%)\end{array}$ \\
\hline $\begin{array}{l}\text { Is the BITWINE virtual platform similar to a } \\
\text { real winery? }\end{array}$ & 57.1 & 28.6 & 14.3 & 0 & 0 \\
\hline $\begin{array}{l}\text { Does using BITWINE create a positive } \\
\text { learning experience? }\end{array}$ & 64.3 & 28.6 & 7.1 & 0 & 0 \\
\hline Did you learn about winery on-the-job safety? & 57.2 & 28.6 & 7.1 & 7.1 & 0 \\
\hline Is safety well-demonstrated in BITWINE? & 64.5 & 7.1 & 21.4 & 7.0 & 0 \\
\hline $\begin{array}{l}\text { Did you understand the safety guidelines } \\
\text { in wineries? }\end{array}$ & 42.9 & 28.6 & 21.4 & 0 & 7.1 \\
\hline $\begin{array}{l}\text { Do you consider that BITWINE treated } \\
\text { practical traceability well? }\end{array}$ & 42.9 & 28.6 & 21.4 & 0 & 7.1 \\
\hline Did you learn about practical winery hygiene? & 71.4 & 14.3 & 14.3 & 0 & 0 \\
\hline $\begin{array}{l}\text { Do you think that BITWINE considered } \\
\text { hygiene well? }\end{array}$ & 64.3 & 28.6 & 7.1 & 0 & 0 \\
\hline $\begin{array}{l}\text { Did you ever have any trouble with } \\
\text { internet connection? }\end{array}$ & 35.7 & 14.3 & 28.6 & 21.4 & 0 \\
\hline $\begin{array}{l}\text { Did you ever have any trouble with } \\
\text { computer capacity? }\end{array}$ & 28.6 & 21.4 & 28.6 & 14.3 & 7.1 \\
\hline
\end{tabular}

Note: Personal compilation. 
The functionality of BITWINE under current conditions in Chile: The last two answers in Table 3 reflect that BITWINE did not work well under inadequate conditions of Information and Communications Technology (ICT). This lead us to be more reflexiveabout the fact that technologies themselves do not directly make learning happen but address certain tasks which may result in learning (Dalgarno, \& Lee, 2010). This is an important issue to be solved because we experienced some problems regarding computer capacity and Internet connectivity in high schools. During the study, it became apparent that the Chilean Information and Communication Technology (ICT) infrastructure is not well developed, despite being considered the most advanced in South America (Donoso, 2010; Voogt, Knezek, Cox, Knezek, \& ten Brummelhuis, 2013).

On the other hand, the role of teachers using ICT for learning is another key aspect to be worked on, especially when problems appear. Usually, the ICT facilities do not reach rural areas (Donoso, 2010) and this is hampering the teachers' work. Amor, Hernando-Gómez and AguadedGómez (2011) found that ICT tools were not well utilized in schools, as a result of the inertia of the school director and the teachers; typically, the ICT projects in use had been developed by just a few teachers, headed by an ICT coordinator. In a specific study about Chilean students' computer use, Claro et al. (2012) found important weaknesses in developing computing, as well other skills; the majority of the students use ICT tools at a very basic level; however, BITWINE demands a pedagogical orientation to promote more creative and deliberative use of computers.

The compatibility between use and users and the ability to take advantage of computers for training depends on the infrastructure, resources, and context characteristics. Specifically, learners with poorer (below the median) economic, social, and cultural capital may be immersed in a cultural context that is far removed from ICT, causing an impossible-to-bridge digital division between ICT and the users (OECD, 2010). The prospective users of BITWINE (rural students, technicians, and operators, along with their teachers and schools) could be at a disadvantage because they typically fall under these "poorer" conditions.

Even with the improved infrastructure and specialized curriculum in most of the educational centers teaching wine production in Chile, the system is insufficient when it comes to meeting the increasing demands for highly skilled workers who need specialized teachers within the wine industry (Fredes, \& Viacava, 2007). Until problems such as the basic weaknesses in teaching or the lack of teachers are not solved, it is impossible for ICT to have a positive impact (Amor et al., 2011). Even with enough teachers, many barriers could still be encountered in integrating ICT into education, the major one being a combination of lack of confidence, lack of competence and lack of resources (Bingimlas, 2009). As a result, the educational system, with inadequate infrastructure and insufficient teachers, is producing a high portion of students who cannot take advantage of BITWINE since its use depends on the technological capacity of schools, as well as on competent human resources in these institutions, as noted in (Voogt et al., 2013) regarding ICT best practices. 
doi: http://dx.doi.org/10.15359/ree.22-2.13

URL: http://www.una.ac.cr/educare

CORREO: educare@una.cr

Although BITWINE has been incorporated into the national curriculum of all Chilean agricultural high schools specialized in winemaking in 2014 (Ministerio de Educación, Chile, 2015), the potential use in Chile for the wine industry is low. The country has 339 wineries to process grapes from 130.000 ha. Other Spanish-language countries such as Argentina (218.000 ha) and especially Spain are bigger markets. Spain has 4.077 wineries that process 1.000 .000 ha approximately. Furthermore, there are very important industries such as South Australia, California (USA), France and Italy (OIV, 2015), but these would require translation of BITWINE. It seems that BITWINE has more potential for uptake abroad than in Chile. Yet, wherever it may get to, the potential for effective use of BITWINE depends on the provision of sufficient resources to ensure its functionality and usability.

\section{Conclusions}

The BITWINE system was designed in an attempt to improve students and workers'technical knowledge and skills in the wine industry. Our results demonstrated that, after students practiced some winemaking processes, they improved their knowledge, theoretical understanding and practical norms of job safety, traceability and hygiene, compared with students without BITWINE. The program was also highly likeable. Some advantages that users mentioned were: the virtual winery itself, attractively designed equipment and details, its likeability and winemaking well described. Job safety, traceability, and hygiene norms were also well simulated. On the other hand, as the program simulates reality well, some key winemaking processes were easier to explain, and allowed a more dynamic teaching process, which in turn produced better student commitment in paying attention and higher interest in using the program.

The findings of this study showed that the BITWINE was beneficial in enhancing students' knowledge, abilities, and skills. The results demonstrated that those students using BITWINE autonomously (i.e., specialized students of oenology) developed competences faster than the control group who studied only in the classroom. Nevertheless, the ICT conditions must be taken into account for the use of any VLE in order to reach a correct functionality of the program, and thereafter produce learning outcomes.

Acknowledgements: We are grateful to the students who participated in this project and especially to the grant CONICYT Chile, FONDEF project $N^{\circ}$ TE10I009 for their support.

\section{References}

Alfaro, J. A., \& Rábade, L. A. (2009). Traceability as a strategic tool to improve inventory management: A case study in the food industry. International Journal of Production Economics, 118(1), 104-110. doi: https://doi.org/10.1016/j.ijpe.2008.08.030 
Amor, M., Hernando-Gómez, Á., \& Aguaded-Gómez, I. (2011). La integración de las TIC en los centros educativos: Percepciones de los coordinadores y directores. Estudios Pedagógicos, 37(2), 197-211. doi: https://doi.org/10.4067/S0718-07052011000200012

Bingimlas, K. A. (2009). Barriers to successful integration of ICT in teaching and learning environment: A review of the literature. Eurasia Journal of Mathematics, Science \& Technology Education, 5(3), 235-245. doi: https://doi.org/10.12973/ejmste/75275

Bisson, L. F., Waterhouse, A. L., Ebeler, S. E., Walker, M. A., \& Lapsley, J. T. (2002). The present and future of the international wine industry. Nature, 418, 696-699. doi: https://doi. org/10.1038/nature01018

Brough, J. E., Schwartz, M., Gupta, S. K., Anand, D. K., Kavetsky R., \& Pettersen, R. (2007). Towards the development of a virtual environment-based training system for mechanical assembly operations. Virtual Reality, 11(4), 189-206. doi: https://doi.org/10.1007/s10055-007-0076-4

Burke, M. J., Sarpy, S. A., Tesluk, P. E., \& Smith-Crowe, K. (2002). General safety performance: A test of a grounded theoretical model. Personnel Psychology, 55(2), 429-457. doi: https://doi. org/10.1111/j.1744-6570.2002.tb00116.x

Cheng, Y., \& Wang, S-H. (2011). Applying a 3D virtual learning environment to facilitate student's application ability - The case of marketing. Computers and Human Behavior, 27(1), 576584. doi: https://doi.org/10.1016/j.chb.2010.10.008

ChileValora. (2015). Sistema Nacional de Certificación de Competencias laborales. Guía de evaluación y certificación de competencias labores. Chile: Autor. Retrieved from http:// www.chilevalora.cl/wp-content/uploads/2017/04/1-D005-04-13-Gu\%C3\%ADa-deevaluaci\%C3\%B3n-y-certificaci\%C3\%B3n-de-CL.pdf

Claro, M., Preiss, D. D., San Martín, E., Jara, I., Hinostroza, J. E., Valenzuela, S., ... Nussbaum, M. (2012). Assesment of 21 st century ICT skills in Chile:Test design and results from high school level students. Computer \& Education, 59(3), 1042-1053. doi: https://doi.org/10.1016/j. compedu.2012.04.004

Dalgarno, B., \& Lee M .J.W. (2010). What are the learning affordances of 3-D virtual environments? British Journal of Educational Technology, 41(1), 10-32. doi: https://doi.org/10.1111/j.14678535.2009.01038.x

Donoso, G. (2010). Enlaces en el sistema escolar chileno: Evolución de sus cifras. En A. Bilbao, \& A. Salinas (Eds.), El libro abierto de la informática educativa. Lecciones y desafíos de la Red Enlaces (pp. 138-149). Santiago: Publicación de Enlaces, Centro de Educación y Tecnología del Ministerio de Educación. Retrieved from https://aulamagica.files.wordpress. com/2010/10/libro abierto enlaces final.pdf 
doi: http://dx.doi.org/10.15359/ree.22-2.13

URL: http://www.una.ac.cr/educare

CORREO: educare@una.cr

Dos Santos, I., Soares, L. P., Carvalho, F., \& Raposo, A. (2012). A collaborative virtual reality oil \& gas workflow. The International Journal of Virtual Reality, 11(1), 1-13. Retrieved from https:// webserver2.tecgraf.puc-rio.br/ abraposo/pubs/IJVR/CEE IJVR2012.pdf

Echeverría, A., Améstica, M., Gil, F., Nussbaum, M., Barrios, E., y Leclerc, S. (2012). Exploring different technological platforms for supporting co-located collaborative games in the classroom. Computers in Human Behavior, 28(4), 1170-1177. doi: https://doi.org/10.1016/j. chb.2012.01.027

Egan, M. B., Raats, M. M., Grubb, S. M., Eves, A., Lumbers, M. L., Dean, M. S., \& Adams, M. R. (2007). A review of food safety and food hygiene training studies in the commercial sector. Food Control, 18(10), 1180-1190. doi: https://doi.org/10.1016/j.foodcont.2006.08.001

Fredes, C., \& Viacava, A. (2007). Red Vitivinícola de la región del Maule. Advanced in a development of a project. Poster session presented at the 13th symposium of Australian Wine Industry Technical Conference, Adelaide, Australia.

Gamberini, L., Cottone, P., Spagnolli, A., Varotto, D., \& Mantovani, G. (2003). Responding to a fire emergency in a virtual environment: Different patterns of action for different situations. Ergonomics, 46(8), 842-858. Doi: https://doi.org/10.1080/0014013031000111266

Green, F., Ashton, D., \& Felstead, A. (2001). Estimating the determinants of supply of computing, problem-solving, communication, social and teamworking skills. Oxford Economic Papers, 53(3), 406-433. Retrieved from doi: https://doi.org/10.1093/oep/53.3.406

International Organization of vine and wine. (2015). Estadísticas. Retrieved from http://www.oiv. int/es/bases-de-datos-y-estadisticas/estadisticas

Jou, M., \& Wang, J. Y (2013). Investigation of effects of virtual reality environments on learning performance of technical skills. Computers in Human Behaviour, 29(2), 433-438. doi: $\underline{\text { https:// }}$ doi.org/10.1016/j.chb.2012.04.020

Leronutti, L., \& Chittaro, L. (2007). Employing virtual humans for education and training in X3D/VRML worlds. Computers \& Education, 49(1), 93-109. Doi: https://doi.org/10.1016/j. compedu.2005.06.007

Ministerio de Educación, Chile. (2014). Ministerio de Educación. Educación Técnico Profesional. Retrieved from http://www.tecnicoprofesional.mineduc.cl

Ministerio de Educación, Chile. (2015). Especilidad agropecuaria. Sector agropecuario. Menciones: Agricultura, pecuaria y vitivinícola. Programa de estudio Formación diferenciada técnicoprofesional $3^{\circ}$ y $4^{\circ}$ año de Educación Media. Chile: Autor. Retrieved from http://www. curriculumenlineamineduc.cl/605/articles-30013 recurso 18 02.pdf 
OECD. (2010). Educational research and innovation: Are the new millennium learners making the grade?: Technology use and educational performance in Pisa 2006. Paris: OECD.

Richards, D., \& Taylor, M. (2015). A Comparison of learning gains when using a 2D simulation tool versus a 3D virtual world: An experiment to find the right representation involving the Marginal Value Theorem. Computers \& Education, 86, 157171. doi: https://doi.org/10.1016/j. compedu.2015.03.009

Rutten, N., van Joolingen, W. R., y van der Veen, J. T. (2012). The learning effects of computer simulations in science education. Computers \& Education, 58(1), 136-153. doi: https://doi. org/10.1016/j.compedu.2011.07.017

Seth, A., Vance, J. M., \& Oliver, J. H. (2011). Virtual reality for assembly methods prototyping: a review. Virtual Reality, 15(1), 5-20. doi: https://doi.org/10.1007/s10055-009-0153-y

Tam, E. K., Badra, F., Marceau, R. J., Marin, M. A., \& Malowany, A. S. (1999). A web-based virtual environment for operator training [for power systems]. IEEE Transactions on Power Systems, 14(3), 802-808. doi: https://doi.org/10.1109/59.780889

Verhagen, T., Feldberg, F., Van den Hooff, B., Meents. S., y Merikivi, J. (2011). Satisfaction with virtual worlds: An integrated model of experiential value. Information, \& Management, 48(6), 201-207. doi: https://doi.org/10.1016/j.im.2011.02.004

Voogt, J., Knezek, G., Cox, M., Knezek D., \& ten Brummelhuis, A. (2013). Under wich conditions does ICT have a positive effect on teaching and learning? A call to action. Journal of Computer Assisted Learning, 29(1), 4-14. doi: https://doi.org/10.1111/j.1365-2729.2011.00453.x

Zhou, J., Lee, I., Thomas, B., Menassa, R., Farrant, A., y Sansome, A. (2012). In-situ support for automotive manufacturing using spatial augmented reality. The International Journal of Virtual Reality, 11(1), 33-41. Retrieved from http://wearables.unisa.edu.au/ uploads/2013/10/insitusupport.pdf 